\title{
CONFORMATIONAL AND CONFIGURATIONAL DIVERSITY OF SOLVENT INCLUSION COMPLEXES OF SOME CALIX[4]PYRROLES AND THEIR ANION RECOGNITION PROPERTIES
}

\author{
A. Sharma ${ }^{1}$, S. Obrai ${ }^{2}$, R. Kumar ${ }^{3}$, A. Kaur ${ }^{4}$, M.S. Hundal ${ }^{4}$ \\ ${ }^{1}$ Department of Chemistry, Hans Raj Mahila Maha Vidyalaya, Jalandhar, Punjab, India \\ E-mail: apparna_2007@yahoo.com \\ ${ }^{2}$ Department of Chemistry, Dr. B.R. Ambedkar National Institute of Technology, Jalandhar, Punjab, India \\ ${ }^{3}$ Department of Chemistry, Lyallpur Khalsa College of Engineering, Jalandhar, Punjab, India \\ ${ }^{4}$ Department of Chemistry, Guru Nanak Dev University, Amritsar, Punjab, India
}

Received August, 4, 2014

Revised November, 13, 2014

\begin{abstract}
Sterically hindered meso-tetramethyl-meso-tetraarylcalix[4]pyrroles $\mathbf{1 - 4}$ where aryl is $p$-fluorophenyl 1, $p$-chlorophenyl 2, and p-methylphenyl 3, 4 (configurational isomers) are synthesized and purified by the recrystallization technique. They are characterized by $\mathrm{IR},{ }^{1} \mathrm{H}$ and ${ }^{13} \mathrm{C} \mathrm{NMR}$, and mass spectroscopy. Configurational isomers $\alpha \alpha \beta \beta(3)$ and $\alpha \alpha \alpha \alpha$ (4) of meso-tetramethylmeso-tetramethylphenylcalix[4]pyrroles are assigned by the ${ }^{1} \mathrm{H}$ NMR studies and confirmed by the X-ray diffraction analysis. The single crystal X-ray diffraction analysis reveals that the ethanol adduct of $\mathbf{1}$, the acetone adduct of $\mathbf{2}$ and $\mathbf{3}$ adopt the 1,2-conformation while the acetone-water adduct of $\mathbf{1}$ and the acetone adduct of $\mathbf{4}$ adopt partial cone and cone conformations respectively. The conformational diversity is due to non-covalent interactions among the encapsulated guest, pyrrolic NH protons, and meso- substituents. Anion binding studies $\left(\mathrm{F}^{-}, \mathrm{Cl}^{-}, \mathrm{CH}_{3} \mathrm{COO}^{-}, \mathrm{HSO}_{4}^{-}\right)$are carried out through ${ }^{1} \mathrm{H}$ NMR titrations; the binding constants are evaluated using the EQNMR program, displaying that they are more selective towards fluoride rather than other anions with the 1:1 stoichiometry. The configuration of compounds drastically influences the ion-recognition processes.
\end{abstract}

DOI: $10.15372 / \mathrm{JSC} 20150720$

Ke y w o r d s: recrystallization, configurational diversity, crystal structure, solvent inclusion complexes, anion recognition, ${ }^{1} \mathrm{H}$ NMR titration.

\section{INTRODUCTION}

Research interest in calix[4]pyrroles is continuously increasing due to their anion [1], neutral molecule [2], and ion pair binding abilities [3] and their potential to be used as optical sensors [4], molecular switching systems [5], electrochemical sensors [6], ion selective electrodes [7], and HPLC supports [ 8]. Calix[4 ]pyrroles, also known as porphyrinogens, are non-conjugated macrocyclic species composed of four pyrrole rings linked in the $\alpha$ position via $s p^{3}$ hybridized carbon atoms. They have a cup-shaped skeleton with four acidic pyrrolic hydrogen atoms that made them superior and potential receptors with unique supramolecular characteristics [9]. Structural flexibility is a distinctive feature of calix[4]pyrrole since it can take up four different type of conformations, viz. 1,3alternate, partial cone, 1,2-alternate, and cone conformations. The conformation type adopted by the calix[4]pyrrole macrocycle depends on various factors such as the nature of guest and the type of substituents at meso- and $\beta$-pyrrolic positions, etc. They generally adopt 1,3- and cone conformations

(C) Sharma A., Obrai S., Kumar R., Kaur A., Hundal M.S., 2015 
in the presence of neutral molecules [2] and anions [1] respectively. However, with an increase in the solvent polarity, a fraction of the 1,2-conformation increases [9]. The switching of conformations in the presence of different guest molecules and the inversion of selectivity in the anion recognition with conformationally blocked calix[4]pyrroles have also been reported [10]. Aryl extended calix[4]pyrroles generally adopt the cone conformation in the presence of polar solvents and anions while in non-polar solvents they adopt the 1,3-conformation in the solution and the solid state [11]. Di-meso-aromatic substituted calix[4]pyrroles sometimes adopt the 1,2-alternate conformation, however, the 1,3-alternate conformation has also been reported [12]. The presence of various substituents at meso- and C-rim of pyrrole also influence the conformational characteristics leading to the stabilization of unusual conformations of the molecule owing to new bonding modes involving strong and weak hydrogen bonding and weak $\pi-\pi$ interactions [13 ]. It was demonstrated that aryl extended calix[4]pyrroles were capable of showing self-assembly [14 ].

The anion binding ability has been modified by introducing different substitutents at C-rim [13] or meso- [15] carbon of calix[4]pyrroles. Calix[4 ]pyrrole bearing substituted aryl groups at mesopositions influence the steric environment as well as the electronic properties of the molecule, thereby enhancing the selectivity for the fluoride anion relative to chloride and dihydrogenphosphate anions [11a ]. By a further extension of the cavity of such molecules it is possible to "switch-off" the binding of anions other than the fluoride ion [16].

Inspired by these studies, we first focused on the convenient synthesis of substituted acetophenone-based calix[4]pyrroles using a modified recrystallization protocol [11a] and then explored their anion binding properties using ${ }^{1} \mathrm{H}$ NMR titrations. Conformations of their solvent inclusion complexes were examined using X-ray crystallography [17] as a structural tool. The solid state studies not only confirmed the proposed structures of meso-aryl substituted derivatives reported here but also revealed the presence of supramolecular interactions among calix[4]pyrrole derivatives and encapsulated solvents. Electron withdrawing and electron releasing aryl groups as meso-substituents were selected to study their effect on the anion binding properties of calix[4]pyrroles. Aryl substituents has a potential to involve in anion $-\pi$ interactions [ $15 \mathrm{c}$ ] and also provide acidic $\mathrm{CH}$ units capable of forming additional hydrogen bonds with guests.

\section{EXPERIMENTAL}

General. Melting points were determined on a Gallenkemp electrically heated apparatus in open capillaries and were uncorrected. ${ }^{1} \mathrm{H}$ and ${ }^{13} \mathrm{C}$ NMR were recorded in $\mathrm{CDCl}_{3}$ on a Bruker Avance II 400 NMR spectrophotometer using tetramethylsilane as the internal standard and chemical shifts were expressed in ppm. FTIR spectra were recorded on a FT Perkin Elmer RXI-FTIR spectrophotometer using $\mathrm{KBr}$ (solid) as the medium and were expressed in $\mathrm{cm}^{-1}$. Mass spectra were recorded on a Waters micromass Q_TOF MicroTM. X-ray crystallographic data were collected on a Bruker APEX-II CCD area detector diffractometer using graphite-monochromated $\operatorname{Mo} K_{\alpha}$ radiation $(\lambda=.71073 \AA)$ source. The crystal structures were solved by a direct method using the SIR-97 program and refined by fullmatrix least-squares refinement methods based on $F^{2}$, using the SHELXL-97 program. All the CH hydrogen atoms were attached geometrically. Molecular structures of the compounds were drawn with the help of the ORTEP program [17]. Pyrrole and ketones were distilled immediately prior to the use.

Representative experimental procedure for the synthesis. Meso-tetramethyl-meso-tetra(4fluorophenyl)calix[4]pyrrole 1, 4-fluoroacetophenone $(6.05 \mathrm{ml}, 0.05 \mathrm{~mol})$, and freshly distilled pyrrole $(3.45 \mathrm{ml}, 0.05 \mathrm{~mol})$ were dissolved in methanol $(150 \mathrm{ml})$ in a round bottom flask. To this mixture hydrochloric acid $(3.0 \mathrm{ml})$ was added dropwise with constant stirring. The resulting mixture was stirred at room temperature until the reaction was completed. On completion of the reaction, the product was separated out as a sticky mass containing a mixture of configurational isomers, which after decanting off mother liquor was thoroughly washed with water and methanol to remove any unreacted pyrrole, ketone, and acid. Finally, it was dissolved in acetone, the white precipitates of the $\alpha \alpha \beta \beta$ isomer was separated out, thoroughly washed with acetone, and crystallized from chloroform-ethanol/chloroformacetone. A single spot on TLC confirmed the purity of the compound. 
Meso-tetramethyl-meso-tetra(4-chlorophenyl)calix[4]pyrrole $(\alpha \alpha \beta \beta)$ 2. Compound 2 was also synthesized using a similar procedure with 4-chloroacetophenone.

Meso-tetramethyl-meso-tetra(4-methylphenyl)calix[4]pyrrole $(\alpha \alpha \beta \beta) 3$ and meso-tetramethylmeso-tetra(4-methylphenyl)calix[4]pyrrole $(\alpha \alpha \alpha \alpha) 4$. Compounds 3 and 4 were also synthesized using a similar procedure with 4-methylacetophenone as the starting material. Two configurational isomers ( $\alpha \alpha \beta \beta 3$ and $\alpha \alpha \alpha \alpha 4)$ of meso-tetramethyl-meso-tetra(4-methylphenyl)calix[4]pyrrole were isolated by recrystallization. The crude sticky mass containing a mixture of configurational isomers was dissolved in acetone, which on standing gave white precipitates of $\alpha \alpha \beta \beta$ isomer 3 that was then thoroughly washed with acetone and crystallized from the chloroform-acetone solution. $\alpha \alpha \alpha \alpha$ Isomer 4 was isolated from the residual acetone solution. A single spot on TLC confirmed the purity of both compounds.

Anion binding studies. ${ }^{1} \mathrm{H}$ NMR titrations. $1 \mathrm{H}$ NMR titrations were carried out by the addition of anions $\left(\mathrm{F}^{-}, \mathrm{Cl}^{-}, \mathrm{CH}_{3} \mathrm{COO}^{-}, \mathrm{HSO}_{4}^{-}\right)$as tetrabutylammonium salts to a $0.0045 \mathrm{M}$ solution of compounds in the $\mathrm{CDCl}_{3}$ solvent. After each addition, the NMR spectrum was recorded. The association constants were determined by fitting the dependence of the chemical shift of the $\mathrm{NH}$ signal $(\Delta \delta)$ on the anion concentration, using the EQNMR program.

Spectral data of 1-4. 1: $16.0 \%$; light creamish solid; ${ }^{1} \mathrm{H}$ NMR $\left(\mathrm{CDCl}_{3}, 400 \mathrm{MHz}, \mathrm{ppm}\right): \delta 1.88$ $\left(\mathrm{s}, 12 \mathrm{H}, \mathrm{CH}_{3}\right), 5.7(\mathrm{~d}, 4 \mathrm{H}$, pyrrole- $\mathrm{H}), 5.9(\mathrm{~d}, 4 \mathrm{H}$, pyrrole- $\mathrm{H}), 6.92-6.87(\mathrm{~m}, 8 \mathrm{H}$, phenyl-H), $7.02-$ $6.98(\mathrm{~m}, 8 \mathrm{H}$, phenyl $\mathrm{CH}) 7.60(\mathrm{br}, \mathrm{s}, 2 \mathrm{H}, \mathrm{NH}), 7.62(\mathrm{br}, \mathrm{s}, 2 \mathrm{H}, \mathrm{NH}), 2.08\left(\mathrm{~s}, 6 \mathrm{H}\right.$, acetone- $\left.\mathrm{CH}_{3}\right) ;{ }^{13} \mathrm{C}$ NMR $\left(\mathrm{CDCl}_{3}, 400 \mathrm{MHz}\right): \delta 29.4,30.8,44.2,105.7,106.3,114.4,114.6,128.8,128.9,136.4,136.8$, 143.1, 143.2, 160.2, 162.6, 207.5 ppm; FT-IR $\left(\mathrm{KBr}, \mathrm{cm}^{-1}\right)$ : 3418 (pyrrole NH), 3105 ( $\beta$-pyrrole $\mathrm{C}-\mathrm{H}), 2978,2918,2849,1706,1671,1573,1508,1451,1187,1039,820,762 \mathrm{~cm}^{-1} ; \mathrm{MS}(\mathrm{EI}): \mathrm{m} / \mathrm{z}$ $749.3[\mathrm{M}+]$; CHN: [Found: $\mathrm{C} 72.63, \mathrm{H} 6.53, \mathrm{~N} 7.03, \mathrm{~F} 9.57 . \mathrm{C}_{48} \mathrm{H}_{40} \mathrm{~F}_{4} \mathrm{~N}_{4} \cdot 2\left(\mathrm{C}_{3} \mathrm{H}_{6} \mathrm{O}\right)$ requires $\mathrm{C} 72.71$, H 6.61, N 7.06, F $9.58 \%$ ].

2: $22 \%$; light creamish solid, ${ }^{1} \mathrm{H}$ NMR $\left(\mathrm{CDCl}_{3}, 400 \mathrm{MHz}\right): \delta 1.87\left(\mathrm{~s}, 12 \mathrm{H}, \mathrm{CH}_{3}\right), 5.76-5.77(\mathrm{~d}$, $4 \mathrm{H}$, pyrrole-H), 5.90-5.91 (d, 4H, pyrrole-H), 6.97-7.01 (m, 8H, phenyl-H), 7.17-7.25 (m, 8H, phenyl CH) 7.53 (br, s, 2H, NH), $7.47(\mathrm{br}, \mathrm{s}, 2 \mathrm{H}, \mathrm{NH}), 2.08\left(\mathrm{~s}, 12 \mathrm{H}\right.$, acetone- $\left.\mathrm{CH}_{3}\right) ;{ }^{13} \mathrm{C} \mathrm{NMR}\left(\mathrm{CDCl}_{3}\right.$, $400 \mathrm{MHz}): \delta 29.3,30.92,44.41,106.59,106.05,128.71,128.03,132.44,136.14,136.34,145.8$, 207.6 ppm; IR (KBr): 3381.5, 3435.32 (pyrrole NH), 3105.26( $\beta$-pyrrole C-H), 2977.7, 1667.28, 1568.88, 1487.74 (C-H bending), 1398.84, 1264.75, 1012.67, 832.27, 720.31 $\mathrm{cm}^{-1} ; \mathrm{MS}(\mathrm{EI}): \mathrm{m} / \mathrm{z}$ 815.2 [M+]; CHN: [Found: $\mathrm{C} 66.90, \mathrm{H} 6.15, \mathrm{~N} 6.54, \mathrm{Cl}$ 16.4. $\mathrm{C}_{48} \mathrm{H}_{40} \mathrm{Cl}_{4} \mathrm{~N}_{4} \cdot 2\left(\mathrm{C}_{3} \mathrm{H}_{6} \mathrm{O}\right)$ requires $\mathrm{C} 67.13$, H 6.10, N 6.52, Cl 16.5\%].

3: $26 \%$; light creamish solid, ${ }^{1} \mathrm{H}$ NMR $\left(\mathrm{CDCl}_{3}, 400 \mathrm{MHz}\right): \delta 1.87\left(\mathrm{~s}, 12 \mathrm{H}, \mathrm{CH}_{3}\right), 2.17(\mathrm{~s}, 12 \mathrm{H}$, phenyl- $\left.\mathrm{CH}_{3}\right), 5.73(\mathrm{~d}, 4 \mathrm{H}$, pyrrole- $\mathrm{H}), 5.92(\mathrm{~d}, 4 \mathrm{H}$, pyrrole- $\mathrm{H}), 6.95-6.97(\mathrm{~m}, 8 \mathrm{H}$, phenyl $\mathrm{CH})$, 7.03-7.05 (m, 8H, phenyl-H), 7.40 (br, s, 2H, NH), 7.46 (br, s, 2H, NH), 2.31 (s, 12H, acetone- $\mathrm{CH}_{3}$ ); ${ }^{13} \mathrm{C} \mathrm{NMR}\left(\mathrm{CDCl}_{3}, 400 \mathrm{MHz}\right): \delta 20.93,29.6,30.94,44.40,105.2,106.0,127.2,128.5,135.9,136.8$, 137.2, 144.7 ppm; IR (KBr): 3365.95 (pyrrole NH), 3110.79 ( $\beta$-pyrrole $\mathrm{C}-\mathrm{H}), 2979.32,2871.92$, 1707.34, 1574.28, 1451.36 (C-H bending), 1414.77, 1312.28, 1269.19, 1218.0, 1188.05, 1037.95, $759.65 \mathrm{~cm}^{-1}$; MS(EI): $m / z$ 733.5 [M+]; CHN: [Found: C 81.93, H 7.69, N 6.57. $\mathrm{C}_{52} \mathrm{H}_{52} \mathrm{~N}_{4} \cdot 2\left(\mathrm{C}_{3} \mathrm{H}_{6} \mathrm{O}\right)$ requires $\mathrm{C} 82.03, \mathrm{H} 7.59, \mathrm{~N} 6.59 \%$ ].

4: $30 \%$; light creamish solid, ${ }^{1} \mathrm{H}$ NMR $\left(\mathrm{CDCl}_{3}, 400 \mathrm{MHz}\right): \delta 1.75\left(\mathrm{~s}, 12 \mathrm{H}, \mathrm{CH}_{3}\right), 1.92(\mathrm{~s}, 12 \mathrm{H}$, phenyl- $\left.\mathrm{CH}_{3}\right), 5.84-5.83(\mathrm{~d}, 8 \mathrm{H}$, pyrrole-H), $6.99-6.93(\mathrm{~m}, 16 \mathrm{H}$, phenyl $\mathrm{CH}) 7.96(\mathrm{br}, \mathrm{s}, 4 \mathrm{H}, \mathrm{NH})$, $2.2\left(\mathrm{~s}, 12 \mathrm{H}\right.$, acetone- $\left.\mathrm{CH}_{3}\right) ;{ }^{13} \mathrm{C} \mathrm{NMR}\left(\mathrm{CDCl}_{3}, 400 \mathrm{MHz}\right): \delta 20.86,29.07,30.42,44.27,105.8,127.45$, 128.31, 135.71, 136.86, 145.99, 209.3 ppm; IR (KBr): 3439.5 (pyrrole NH), 3107.7 ( $\beta$-pyrrole $\mathrm{C}-\mathrm{H}$ ), 2980.0, 2924.3, 1705.6, 1574.2, 1452.1 (C-H bending), 1414.9, 1400.6, 1283.1, 1019.7, 822.3, 759.5, $539.4 \mathrm{~cm}^{-1}$; MS(EI): $\mathrm{m} / z 733.5\left[\mathrm{M}+\right.$ ]; CHN: [Found: C 82.01, H 7.54, N 6.60. $\mathrm{C}_{52} \mathrm{H}_{52} \mathrm{~N}_{4}$. $\cdot 2\left(\mathrm{C}_{3} \mathrm{H}_{6} \mathrm{O}\right)$ requires $\mathrm{C} 82.03, \mathrm{H} 7.59, \mathrm{~N} 6.59 \%$ ].

\section{RESULTS AND DISCUSSION}

Meso-tetramethyl-meso-tetra(4-fluorophenyl)calix[4]pyrrole $(\alpha \alpha \beta \beta)$ 1, meso-tetramethyl-mesotetra(4-chlorophenyl)calix[4]pyrrole $\quad(\alpha \alpha \beta \beta) \quad 2$, meso-tetramethyl-meso-tetra(4-methylphenyl)ca- 
lix[4]pyrrole $(\alpha \alpha \beta \beta)$ 3, and meso-tetramethyl-meso-tetra(4-methylphenyl)calix[4]pyrrole ( $\alpha \alpha \alpha \alpha) 4$ were prepared in moderate yields by reacting pyrrole and 4-fluoro/4-chloro/4-methyl acetophenone, catalyzed by hydrochloric acid in methanol at room temperature. The $\alpha \alpha \beta \beta$ isomer of compounds 1 and 2 and two configurational isomers ( $\alpha \alpha \beta \beta 3$ and $\alpha \alpha \alpha \alpha$ 4) were separated by the recrystallization technique.

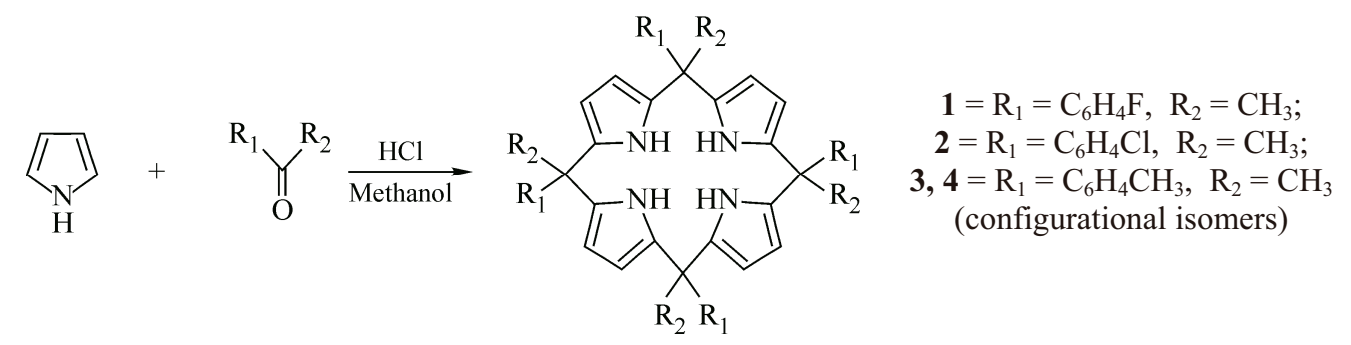

Scheme 1. Synthesis of substituted calix[4]pyrrole

The identity of compounds was verified by IR, ${ }^{1} \mathrm{H}$ and ${ }^{13} \mathrm{C}$ NMR, mass spectroscopy and confirmed by single crystal X-ray crystallography. The stereochemistry of the synthesized compounds was ascertained from their ${ }^{1} \mathrm{H}$ NMR spectra and was further established by X-ray crystallography. The two doublets for pyrrolic $\mathrm{CH}$ protons clearly indicated the $\alpha \alpha \beta \beta$ configuration of $\mathbf{1}, \mathbf{2}$, and 3 while 4 showed only one type of pyrrolic $\mathrm{CH}$ protons indicating the $\alpha \alpha \alpha \alpha$ configuration [11a ]. Solvent inclusion complexes of $\mathbf{1}$ were developed by slow evaporation of the chloroform solution layered with ethanol and acetone separately giving ethanol (1a) and acetone-water (1) b) adducts of $\mathbf{1}$. Acetone inclusion complexes of $\mathbf{2}, \mathbf{3}$, and $\mathbf{4}$ were grown by slow evaporation of the chloroform solution layered with acetone. Single crystal X-ray crystallography revealed that the solvent inclusion complexes adopted inter-

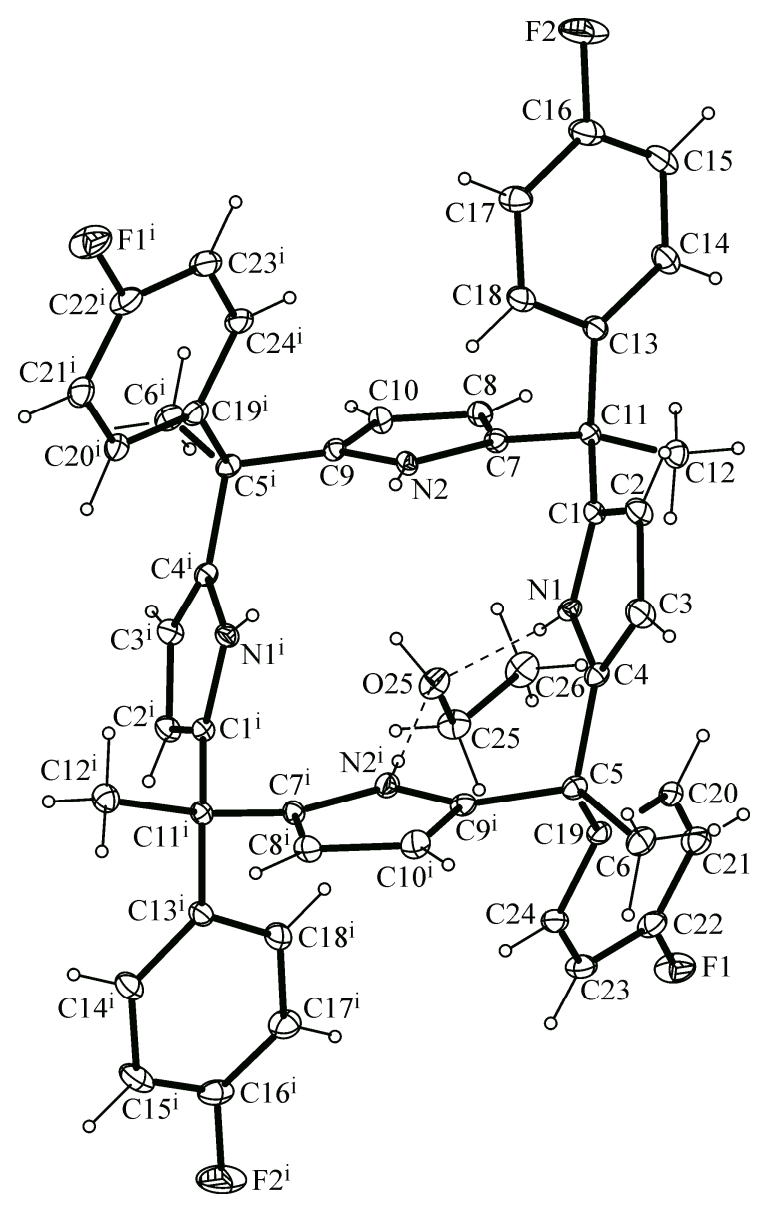
esting geometries with different core conformations.

The crystal structure (Fig. 1) of $\mathbf{1 a}$ (ethanol adduct of meso-tetramethyl-meso-tetra(4-fluorophenyl)calix[4]pyrrole 1) confirms the $\alpha \alpha \beta \beta$ configuration and the 1,2-conformation with ethanol as a guest molecule. Pyrrolic N1 and N2 protons of the titled compound are involved in intramolecular $\mathrm{H}$-bonding interactions with the oxygen atom of the encapsulated ethanol molecule having $\mathrm{N} 1 \ldots \mathrm{O} 25$ and N2...O25 distances $3.006 \AA$ and $2.983 \AA$ respectively (Table 1). In addition to host-guest interactions, weak intermolecular F2...H23 and F1...H12B interactions have also been observed, which lead to the stablization of the 1,2-molecular conformation, as was previously reported in other substituted solvent inclusion complexes [ $9 \mathrm{~d}, 13 \mathrm{c}]$.

$\mathbf{1 b}$ (acetone-water adduct of meso-tetramethylmeso-tetra(4-fluorophenyl)calix[4]pyrrole 1) crystallizes in the space group $C 2 / \mathrm{m}$. It adopts a partial cone conformation (Fig. 2) with three pyrrole units pointing in the same direction and making hydrogen bonds with the oxygen atom of the acetone molecule while the fourth pyrrole moiety points in the opposite direction and is hydrogen bonded with the water

Fig. 1. ORTEP view of the molecular structure of the ethanol adduct of 1 (1a) (1,2-conformation) 
Crystallographic data and the structural refinement method for solvent inclusion complexes

\begin{tabular}{|c|c|c|c|c|c|c|c|c|c|}
\hline $\begin{array}{l}\text { Mole- } \\
\text { cule }\end{array}$ & $\mathrm{D}-\mathrm{H} \ldots \mathrm{A}$ & $d(\mathrm{H} \ldots \mathrm{A}), \AA$ & $d(\mathrm{D} \ldots \mathrm{A}), \AA$ & $\mid \begin{array}{c}\theta(\mathrm{D}-\mathrm{H} \ldots \mathrm{A}) \\
\operatorname{deg} .\end{array}$ & $\begin{array}{l}\text { Mole- } \\
\text { cule }\end{array}$ & $\mathrm{D}-\mathrm{H} \ldots \mathrm{A}$ & $d(\mathrm{H} \ldots \mathrm{A}), \AA$ & $d(\mathrm{D} \ldots \mathrm{A}), \AA$ & $\mid \begin{array}{c}\theta(\mathrm{D}-\mathrm{H} \ldots \mathrm{A}), \\
\text { deg. }\end{array}$ \\
\hline \multirow[t]{3}{*}{ 1a } & $\mathrm{N} 1-\mathrm{H} 1 \ldots \mathrm{O} 25$ & 2.176 & 3.006 & 162.12 & 2 & $\mathrm{~N} 1-\mathrm{H} 1 \ldots \mathrm{O} 1 \mathrm{~A}$ & $2.085(1)$ & $2.925(1)$ & $166.65(4)$ \\
\hline & N2H2A...O25 & 2.132 & 2.983 & 170.53 & & N2H2A...O1A & $2.234(1)$ & $3.035(1)$ & $167.15(3)$ \\
\hline & $\mathrm{O} 25-\mathrm{H} 25 \ldots \mathrm{N} 1$ & $2.841(2)$ & $3.256(2)$ & $114.33(5)$ & 3 & $\mathrm{~N} 1-\mathrm{H} 1 \ldots \mathrm{O} 1 \mathrm{~A}$ & 2.183 & 3.027 & 166.85 \\
\hline \multirow[t]{4}{*}{ 1b } & $\mathrm{N} 1-\mathrm{H} 1 \ldots \mathrm{O} 1$ & 2.391(1) & $3.157(2)$ & $148.62(9)$ & & N2H2A...O1A & 2.060 & 2.907 & 168.20 \\
\hline & $\mathrm{N} 3-\mathrm{H} 3 \mathrm{~A} \ldots \mathrm{O} 1$ & 2.219 & 3.042 & 160.16 & 4 & $\mathrm{~N} 1-\mathrm{H} 1 \mathrm{~A} \ldots \mathrm{O} 2$ & 2.247 & 3.098 & 170.28 \\
\hline & $\mathrm{N} 2 \mathrm{H} 2 \mathrm{~A} \ldots \mathrm{O} 1 \mathrm{~W}$ & 2.209 & 3.065 & 173.16 & & $\mathrm{~N} 2-\mathrm{H} 2 \mathrm{~A} \ldots \mathrm{O} 2$ & 2.295 & 3.154 & 177.17 \\
\hline & & & & & & $\mathrm{N} 3-\mathrm{H} 3 \mathrm{~A} \ldots \mathrm{O} 2$ & 2.238 & 3.096 & 176.12 \\
\hline
\end{tabular}

oxygen atom (Table 1). This structure shows the rare example of calix[4]pyrrole presenting the partial cone conformer, as is observed for the acetone adduct of meso-indanylcalix[4]pyrrole [ $9 \mathrm{e}$ ] and the acetonitrile adduct of meso-tetramethyltetramethoxyphenylcalix[4]pyrrole [11a]. Small inorganic molecules in the lattice often bring consider able variation in the conformation, as has previously been reported $[12 \mathrm{~b}]$. The present molecule also proves this, since the water molecule played an important role in the stabilization of the rare partial cone conformation. Intermolecular interactions other than the host-guest binding between $\mathrm{H} 16 \ldots \mathrm{C} 2$ is also observed in this solvent inclusion complex.

The acetone adduct of mesotetramethyl-meso-tetra(4-chlorophenyl)calix[4]pyrrole 2 crystallizes in the space group $P-1$. The X-ray crystal structure (Fig. 3) confirms the $\alpha \alpha \beta \beta$ configuration assigned by ${ }^{1} \mathrm{H}$ NMR spectroscopy. The acetone adduct of $\mathbf{2}$ adopts the 1,2-alternate conformation in which two adjacent pyrrole rings point in the same direction while the other two point in the opposite direction, as is reported for the DMF adduct of meso-indanylsubstituted calix[4]pyrrole [9e ]. Pyrrolic N1 and N2 protons of the titled compound are involved in H-bonding interactions with the oxygen atom of encapsulated acetone having N1...O1A and $\mathrm{N} 2 \ldots \mathrm{O} 1 \mathrm{~B}$ distances of $2.925(1) \AA$ and 3.035(1) ^ respectively. Substituents exert their own effect in adopting conformations, for example

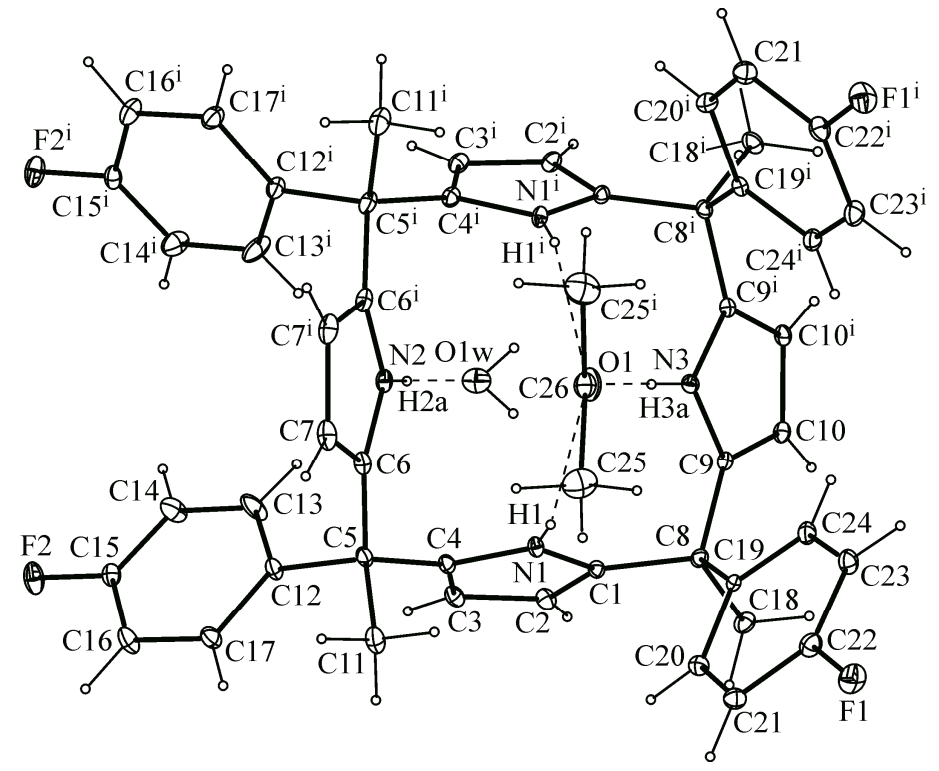

Fig. 2. ORTEP view of the molecular structure of the acetone water adduct of 1: $\left(\mathrm{CH}_{3}\right)_{2} \mathrm{CO} \cdot \mathrm{H}_{2} \mathrm{O}(\mathbf{1 b})$ (partial cone conformation)

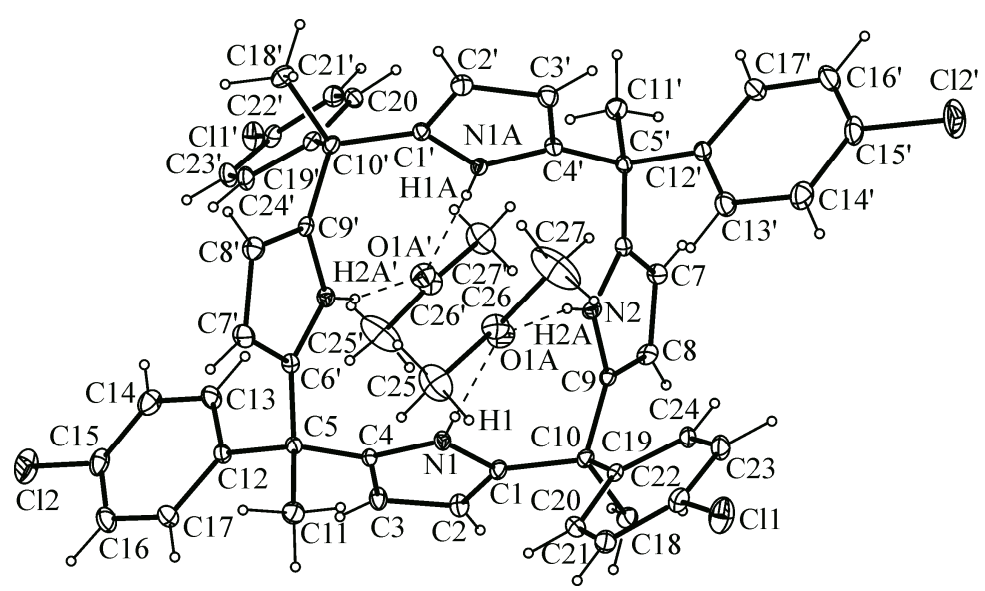

Fig. 3. ORTEP view of the molecular structure of the acetone adduct of $2\left(2 \mathrm{CH}_{3} \mathrm{COCH}_{3}\right)$ (1,2-conformation) 
octa-bromocalix[4]pyrrole showed the conformation in between 1,2- and 1,3-owing to the presence of eight peripheral bromine atoms [13c ]. Similarly the chlorine atom at the para-position of the phenyl ring in the acetone adduct of 2 leads to secondary hydrogen bonding interactions between C11...H11B $(2.898 \AA)$ and $\mathrm{C} 12 \ldots \mathrm{H} 23(2.867 \AA)$ that is responsible for the stabilization of the 1,2-conformation. Generally, the encapsulation of polar solvents by calix[4]pyrrole containing deep cavities makes it adopt the cone conformation [11a ].

The acetone adduct of meso-tetramethyl-meso-tetra(4-methylphenyl)calix[4]pyrrole 3 crystallizes in the space group $P$-1. The crystal structure (Fig. 4) confirmed the $\alpha \alpha \beta \beta$ configuration and the 1,2conformation with acetone as a guest molecule, like other polar solvent encapsulated complexes [ $9 \mathrm{a}$ ]. Pyrrolic NH protons ( $\mathrm{N} 1$ and $\mathrm{N} 2$ ) of the titled compound are involved in $\mathrm{H}$-bonding interactions with the oxygen atom of encapsulated acetone having N1...O1A and N2...O1A distances of 3.027(4) $\AA$ and $2.907(3) \AA$ respectively (Table 1). In addition to host - guest interactions, weak intermolecular interactions between H6...H24B (2.278 $⿱$ $)$ have also been observed, leading to the stablization of the 1,2molecular conformation, as was previously reported for other solvent inclusion complexes [ $9 \mathrm{~d}, 13 \mathrm{c}$ ].

Tne adduct of meso-tetramethyl-meso-tetra(4-methylphenyl)calix[4]pyrrole 4 crystallizes in the

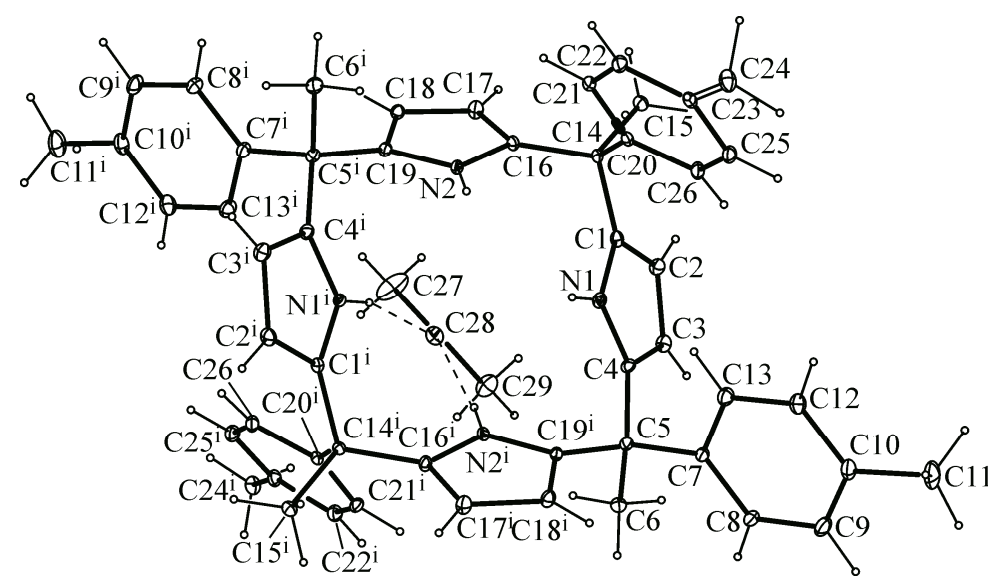

Fig. 4. ORTEP view of the molecular structure of the acetone adduct of $\mathbf{3}\left(2 \mathrm{CH}_{3} \mathrm{COCH}_{3}\right)$ (1,2-conformation)

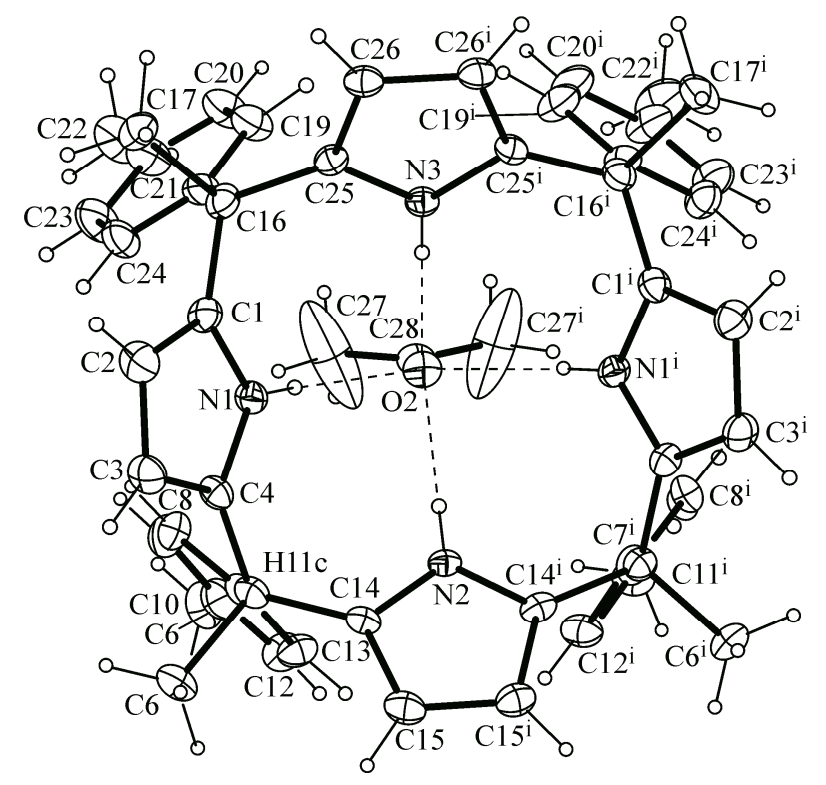

Fig. 5. ORTEP view of the molecular structure of the acetone adduct of $4\left(2 \mathrm{CH}_{3} \mathrm{COCH}_{3}\right)$ (cone conformation) space group Pnma. The X-ray crystal structure (Fig. 5) confirms the $\alpha \alpha \alpha \alpha$ configuration and the cone conformation with acetone as a guest molecule like other solvent encapsulated complexes [11a] having the $\alpha \alpha \alpha \alpha$ configuration. Pyrrolic NH protons (N1 and N2) of the titled compound are involved in H-bonding interactions with the oxygen atom of encapsulated acetone having $\mathrm{N} 1 \ldots \mathrm{O} 2, \mathrm{~N} 2 \ldots \mathrm{O} 2$ and $\mathrm{N} 3 \ldots \mathrm{O} 2$ distances of 3.098(4) $\AA, 3.303(4) \AA$, and 3.096(5) A respectively (Table 1 ). In addition to host-guest interactions, weak intermolecular interactions between $\mathrm{H} 8 \ldots \mathrm{H} 9$ (2.371 $\mathrm{\AA}$ ) have also been observed. The presence of hydrogen bond donors and acceptors in these functionalized calix[4]pyrroles suggests that they may act as receptors for a variety of substrates under solution-phase conditions. The crystallographic data for the synthesized solvent inclusion complexes are summarized in Table 2.

The binding properties of substituted calix[4]pyrroles $\mathbf{1}-\mathbf{4}$ with different anions $\left(\mathrm{F}^{-}, \mathrm{Cl}, \mathrm{HSO}_{4}^{-}\right.$, $\mathrm{CH}_{3} \mathrm{COO}^{-}$) were investigated by ${ }^{1} \mathrm{H}$ NMR titrations in $\mathrm{CDCl}_{3}$ by observing shifts of pyrrole $\mathrm{N}-\mathrm{H}$ protons at room temperature. Data analysis, stability constants, and binding profiles of the calix[4]pyrrole-anion complex (1:1) were calculated using 
$\mathrm{Tab} 1 \mathrm{e} 2$

Selected hydrogen bonding of $\mathbf{1}-\mathbf{4}$

\begin{tabular}{|c|c|c|c|c|c|}
\hline Parameter & $1 \mathrm{a}$ & $1 b$ & $2.2\left(\mathrm{C}_{3} \mathrm{H}_{6} \mathrm{O}\right)$ & $3.2\left(\mathrm{C}_{3} \mathrm{H}_{6} \mathrm{O}\right)$ & $4.2\left(\mathrm{C}_{3} \mathrm{H}_{6} \mathrm{O}\right)$ \\
\hline Empirical formula & $\mathrm{C}_{48} \mathrm{H}_{40} \mathrm{~F}_{4} \mathrm{~N}_{4} \cdot 2\left(\mathrm{C}_{2} \mathrm{H}_{6} \mathrm{O}\right)$ & $\mathrm{C}_{48} \mathrm{H}_{40} \mathrm{~F}_{4} \mathrm{~N}_{4} \mathrm{C}_{3} \mathrm{H}_{6} \mathrm{O} \cdot \mathrm{H}_{2} \mathrm{O}$ & $\mathrm{C}_{48} \mathrm{H}_{40} \mathrm{Cl}_{4} \mathrm{~N}_{4} \cdot 2\left(\mathrm{C}_{3} \mathrm{H}_{6} \mathrm{O}\right)$ & $\mathrm{C}_{52} \mathrm{H}_{52} \mathrm{~N}_{4} \cdot 2\left(\mathrm{C}_{3} \mathrm{H}_{6} \mathrm{O}\right)$ & $\mathrm{C}_{52} \mathrm{H}_{52} \mathrm{~N}_{4} \cdot 2\left(\mathrm{C}_{3} \mathrm{H}_{6} \mathrm{O}\right)$ \\
\hline Formula weight & 840.98 & 824.93 & 930.80 & 849.13 & 849.13 \\
\hline Crystal system & Triclinic & Monoclinic & Triclinic & Triclinic & Orthorhombic \\
\hline Crystal size & $0.16 \times 0.14 \times 0.11$ & $0.18 \times 0.14 \times 0.09$ & $0.14 \times 0.12 \times 0.11$ & $0.14 \times 0.12 \times 0.10$ & $0.14 \times 0.12 \times 0.10$ \\
\hline Color & Colourless & Creamish & Colourless & White & Colorless \\
\hline Shape & Rectangular & Needle & Rectangular & Rectangular & Plates \\
\hline Space group & $P-1$ & $C 2 / m$ & $P-1$ & $P-1$ & Pnma \\
\hline \multirow{6}{*}{$\begin{array}{l}\text { Unit cell dimensions, } \\
\AA \text { A, deg. }\end{array}$} & $a=10.226(5)$ & $a=13.2110(3)$ & $a=11.045(5)$ & $a=10.9696(18)$ & $a=20.669(2)$ \\
\hline & $b=11.011(5)$ & $b=20.7420(6)$ & $b=11.115(5)$ & $b=11.2098(17)$ & $b=21.070(3)$ \\
\hline & $c=11.019(5)$ & $c=15.7140(4)$ & $c=11.207(5)$ & $c=11.2720(19)$ & $c=11.1987(11)$ \\
\hline & $\alpha=101.218(5)$ & & $\alpha=102.368(5)$ & $\alpha=101.775(10)$ & \\
\hline & $\beta=96.295(5)$ & $\beta=94.8770(10)$ & $\beta=111.737(5)$ & $\beta=111.174(10)$ & $\beta=90$ \\
\hline & $\gamma=112.051(5)$ & & $\gamma=99.026(5)$ & $\gamma=99.601(10)$ & \\
\hline Volume, $\AA^{3}$ & $1105.0(9)$ & $4290.40(19)$ & $1205.3(9)$ & $1220.6(4)$ & $4877.0(10)$ \\
\hline$Z, \rho_{\text {calc. }}, \mathrm{g} \cdot \mathrm{cm}^{-3}$ & $1,1.264$ & $4,1.277$ & $2,1.282$ & $1,1.155$ & $4,1.156$ \\
\hline$\mu, \mathrm{cm}^{-1}$ & 0.089 & 0.090 & 0.291 & 0.070 & 0.070 \\
\hline$F(000)$ & 444 & 1736 & 488 & 456 & 1824 \\
\hline $\begin{array}{l}\theta \text { Range of data } \\
\text { collection }\end{array}$ & 1.92 to 29.65 & 1.83 to 30.49 & 1.94 to 30.82 & 1.92 to 32.99 & 1.93 to 25.50 \\
\hline \multirow[t]{3}{*}{ Limiting frequency } & $-14 \leq h \leq 12$ & $-18 \leq h \leq 18$ & $-15 \leq h \leq 15$ & $-16 \leq h \leq 16$ & $-24 \leq h \leq 23$ \\
\hline & $-15 \leq k \leq 14$ & $-29 \leq k \leq 29$ & $-15 \leq k \leq 15$ & $-17 \leq k \leq 17$ & $-25 \leq k \leq 21$ \\
\hline & $-15 \leq l \leq 15$ & $-17 \leq l \leq 22$ & $-15 \leq l \leq 16$ & $-16 \leq l \leq 17$ & $-13 \leq l \leq 10$ \\
\hline $\begin{array}{l}\text { Total / Independent } \\
\text { reflections }\end{array}$ & $\begin{array}{c}22254 / 6184 \\
{[R(\text { int })=0.0186]}\end{array}$ & $\begin{array}{c}51396 / 6702 \\
{[R(\text { int })=0.0209]}\end{array}$ & $\begin{array}{c}25551 / 7485 \\
{[R(\text { int })=0.0217]}\end{array}$ & $\begin{array}{c}21228 / 7800 \\
{[R(\text { int })=0.0567]}\end{array}$ & $\begin{array}{c}17724 / 4667 \\
{[R(\text { int })=0.0682]}\end{array}$ \\
\hline Completeness to $\theta, \%$ & $29.65,98.9$ & $30.49,99.8$ & $30.82,99.2$ & $32.99,84.9$ & $25.50,99.9$ \\
\hline Refinement method & $\begin{array}{l}\text { Full matrix least } \\
\text { squares on } F^{2}\end{array}$ & $\begin{array}{l}\text { Full matrix least } \\
\text { squares on } F^{2}\end{array}$ & $\begin{array}{l}\text { Full matrix least } \\
\text { squares on } F^{2}\end{array}$ & $\begin{array}{l}\text { Full matrix least } \\
\text { squares on } F^{2}\end{array}$ & $\begin{array}{l}\text { Full matrix least } \\
\text { squares on } F^{2}\end{array}$ \\
\hline Goodness of fit on $F^{2}$ & 1.031 & 1.040 & 1.053 & 1.066 & 0.991 \\
\hline $\begin{array}{l}\text { Final } R \text { indices } \\
\qquad[I>2 \sigma(I)]\end{array}$ & $\begin{array}{c}R 1=0.0680 \\
w R 2=0.2098\end{array}$ & $\begin{array}{c}R 1=0.0672 \\
w R 2=0.1841\end{array}$ & $\begin{array}{c}R 1=0.0538 \\
w R 2=0.1517\end{array}$ & $\begin{array}{c}R 1=0.1007 \\
w R 2=0.2741\end{array}$ & $\begin{array}{l}R 1=0.0730 \\
w R 2=0.1981\end{array}$ \\
\hline$R$ indices (all data) & $\begin{array}{c}R 1=0.0836 \\
w R 2=0.2306\end{array}$ & $\begin{array}{c}R 1=0.0896 \\
w R 2=0.2091\end{array}$ & $\begin{array}{c}R 1=0.0712 \\
w R 2=0.1685\end{array}$ & $\begin{array}{c}R 1=0.1851 \\
w R 2=0.3525\end{array}$ & $\begin{array}{c}R 1=0.1710 \\
w R 2=0.2568\end{array}$ \\
\hline $\begin{array}{l}\text { Largest diff. peak \& } \\
\text { hole, e/ } / \AA^{3}\end{array}$ & $0.910 \&-0.651$ & $0.804 \&-0.606$ & $0.494 \&-0.672$ & $0.413 \&-0.452$ & $0.787 \&-0.345$ \\
\hline
\end{tabular}

the EQNMR computer program [18 ] fitting. The anions were added in the form of tetrabutylammonium salts and the concentration of receptor molecules has been kept constant $(0.0045 \mathrm{M})$ during the experiment. The titration profiles (Fig. 6) showed pronounced changes observed in the NMR spectra of $\mathbf{1}, \mathbf{4}$ on addition of the fluoride ion.

In case of 1, the signal corresponding to the pyrrolic NH protons (Fig. 6) initially observed at $7.31 \mathrm{ppm}$ was shifted to $9.71 \mathrm{ppm}$ on addition of 1.0 equiv. of the fluoride ion, thus showing a downfield shift of the $\mathrm{NH}$ signal $(\Delta \delta=2.40 \mathrm{ppm})$. With increasing $\mathrm{F}^{-}$concentration, the signal shifted further to a lower magnetic field, reaching $10.19 \mathrm{ppm}$ at 2.0 equiv. The anion-induced electronic perturbations in the receptor or host molecule has been further strengthened by the appearance of some changes in the chemical shifts of pyrrolic $\mathrm{C}-\mathrm{H}$ protons (upfield shifts of $0.15 \mathrm{ppm}$ and $0.12 \mathrm{ppm}$ ) and phenylic protons (a downfield shift of $0.04 \mathrm{ppm}$, an upfield shift of $0.02 \mathrm{ppm}$ ) of 5-tetramethyl-5tetra(4-fluorophenyl)calix[4]pyrrole 1 on addition of $1.0 \mathrm{gm}$ eq of the fluoride ion. The chloride ion has also induced a downfield shift of the NH protons $(\Delta \delta=0.21 \mathrm{ppm})$ in same receptor 1 but to a smaller extent, as compared to the fluoride ion. On addition of $1 \mathrm{gm}$ eq of the chloride ion to $\mathbf{1}$, the signal of NH protons shifted from $7.35 \mathrm{ppm}$ to $7.56 \mathrm{ppm}$, showing a downfield shift of $0.21 \mathrm{ppm}$. 

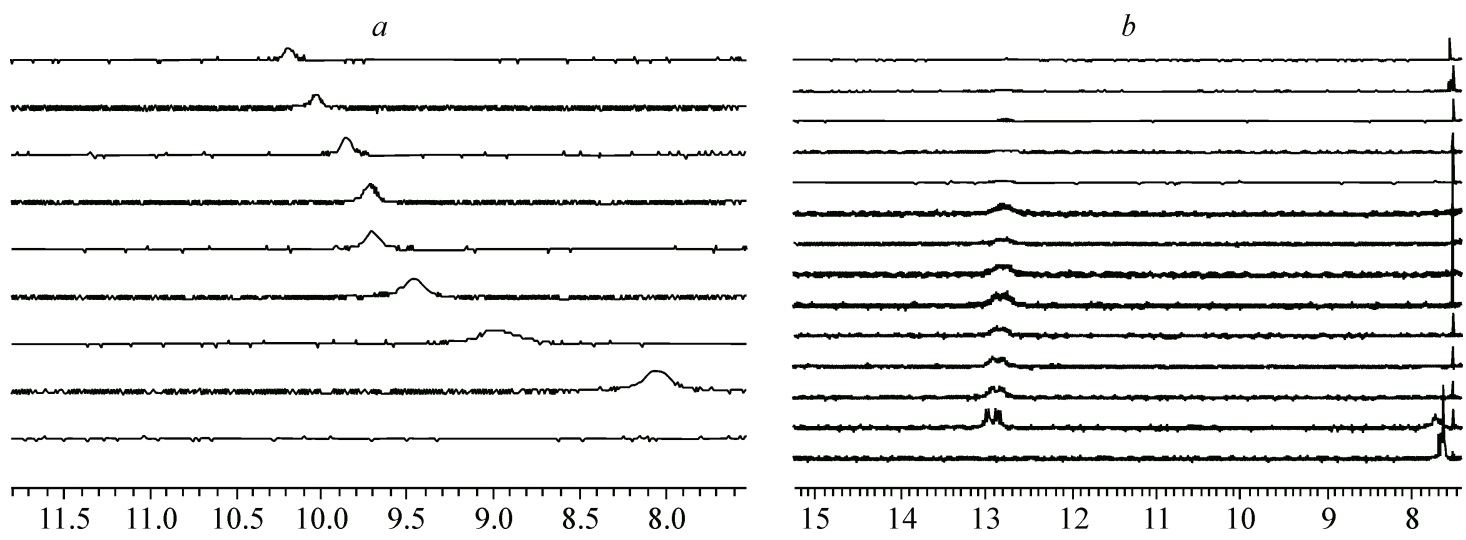

Fig. 6. ${ }^{1} \mathrm{H}$ NMR spectra of $\mathbf{1}(a)$ and $\mathbf{4}(b)$ with a varying $\mathrm{Bu}_{4} \mathrm{NF}$ concentration

It has been found that on addition of $0.25 \mathrm{gm}$ eq of the fluoride ions to 4 (Fig. 7) the signal shifted to $12.9 \mathrm{ppm}$ from $7.64 \mathrm{ppm}$ and on a further addition of the fluoride ion even up to $8.0 \mathrm{gm}$ eq the signal remained approximately at the same position indicating a very strong binding. Also some changes in the chemical shift of the pyrrolic protons (a downfield shift of 0.229) and phenylic (0.1978 upfield) protons of $\mathbf{4}$ have also been observed. However, lower shifts were observed in $\mathbf{3}$ (Table 3 ) as compared to $\mathbf{4}$ on addition of the fluoride ion.

It seems that configuration modifications perturb the ion recognition behaviour because $\alpha \alpha \alpha \alpha$ isomer $\mathbf{4}$ has a high binding constant towards fluoride as compared to $\alpha \alpha \beta \beta$ isomer $\mathbf{3}$. The cavity of $\mathbf{4}$ is deep due to the presence of four phenyl groups on the same side of the macrocyclic plane which may have trapped fluoride leading to a quantitative formation of thecomplex. Two phenyl groups in $\mathbf{3}$ are directed above and the other two below the macrocyclic plane leading to a relatively smaller binding constant towards fluoride than that of $\mathbf{4}$, as was already reported for the configuration isomers of meso-tetramethyltetramethoxyphenylcalix[4]pyrrole [11a ].

The addition of anions $\left(\mathrm{Cl}^{-}, \mathrm{CH}_{3} \mathrm{COO}^{-}, \mathrm{H}_{2} \mathrm{PO}_{4}^{-}\right.$and $\left.\mathrm{HSO}_{4}^{-}\right)$to the solutions of $\mathbf{1}-\mathbf{4}$ also showed a downfield shift of the NH signal (Table 3 ). The lower association constants for chloride and acetate ions can be justified by their bigger size, less basicity and nucleophilicity. This is in accordance with the similar behaviour of the anion sensors with other pyrrole derivatives [1].

The results (Table 4) reveal that the titled compounds are not only the 1:1 anion binding agent in solution for different anions $\left(\mathrm{F}^{-}, \mathrm{Cl}^{-}, \mathrm{HSO}_{4}^{-}, \mathrm{CH}_{3} \mathrm{COO}^{-}\right)$, but they are most selective towards fluoride and least selective towards the acetate ion except 3 that is least selective towards the hydrogensulfate ion. Compound $\mathbf{2}$ is not only selective towards fluoride but shows equally good selectivity for the hydrogensulphate anion, too. We can conclude that the presence of electron withdrawing groups on the aromatic rings $(\mathbf{1}, \mathbf{2})$ enhances the binding constant for different anions, as compared to electron releasing groups (3) (Table 4).

$\mathrm{T}$ a b 1 e 3

$\mathrm{T}$ a b l e 4

Changes in the ${ }^{1} \mathrm{H} \mathrm{NMR}$ chemical shifts $(\Delta \delta, \mathrm{ppm})$ of $\mathrm{NH}$ protons of compounds $\mathbf{1}-\mathbf{4}$ for the interaction with anions (1.0 gm eq) in $\mathrm{CDCl}_{3}$

\begin{tabular}{l|c|c|c|c}
\hline \multicolumn{1}{c|}{ Anion } & \multicolumn{1}{c|}{} & \multicolumn{1}{c|}{} & \multicolumn{1}{c}{$\mathbf{3}$} & \multicolumn{1}{c}{} \\
\hline $\mathrm{F}^{-}$ & 2.40 & 3.1 & 0.33 & 5.26 \\
$\mathrm{Cl}^{-}$ & 0.21 & 0.17 & 0.11 & 0.18 \\
$\mathrm{CH}_{3} \mathrm{COO}^{-}$ & 0.16 & 0.19 & 0.079 & 0.13 \\
$\mathrm{HSO}_{4}^{-}$ & 0.03 & 0.06 & 0.032 & 0.03
\end{tabular}

\begin{tabular}{l|c|l|l|l}
\hline \multicolumn{1}{c|}{ Anion } & $\mathbf{1}$ & \multicolumn{1}{c|}{$\mathbf{2}$} & $\mathbf{3}(\alpha \alpha \beta \beta)$ & $\mathbf{4}(\alpha \alpha \alpha \alpha)$ \\
\hline $\mathrm{F}^{-}$ & $3.65 \pm 0.58$ & $3.7 \pm 0.38$ & $3.51 \pm 0.79$ & $9774^{\mathrm{a}} \pm 207$ \\
$\mathrm{Cl}^{-}$ & $2.88 \pm 0.38$ & $3.0 \pm 0.48$ & $2.12 \pm 0.03$ & $2.40 \pm 0.23$ \\
$\mathrm{HSO}_{4}^{-}$ & $2.12 \pm 0.16$ & $3.52 \pm 0.22$ & $0.50 \pm 0.13$ & $2.23 \pm 0.06$ \\
$\mathrm{CH}_{3} \mathrm{COO}^{-}$ & $1.61 \pm 0.15$ & $1.67 \pm 0.18$ & $1.45 \pm 0.13$ & $1.83 \pm 0.21$
\end{tabular}

${ }^{\mathrm{a}}$ All association constants are $\log _{10} k$ values except which is $k$ value. 


\section{CONCLUSIONS}

Solvent inclusion complexes of meso-tetramethyl-meso-tetraarylcalix[4]pyrroles $\mathbf{1}-\mathbf{4}$ were separated and purified by the recrystallization technique. Crystal structures of receptor-neutral guest complexes are presented showing primary and secondary hydrogen bonding interactions that led to the stabilization of different conformations, space groups, and three dimensional architectures in crystal packing. The encapsulation of different solvent molecules in compound $\mathbf{1}$ has led to the conformational diversity i.e. the adoption of 1,2- and partial cone conformations for $\mathbf{1 a}$ and $\mathbf{1 b}$ respectively. Configurational diversity has also resulted in the conformational diversity since $\alpha \alpha \beta \beta$ isomers (1a, 2 , 3) have 1,2-conformations whereas $\alpha \alpha \alpha \alpha$ isomer (4) has the cone conformation. The receptor-anion recognition behaviour has also been studied by NMR spectroscopy, showing that structural and sterochemical modifications alter the anion binding behaviour. The order of affinities of compounds $\mathbf{1 , 4}$ towards the anions is $\mathrm{F}^{-}>\mathrm{Cl}^{-}>\mathrm{HSO}_{4}^{-}>\mathrm{CH}_{3} \mathrm{COO}^{-}$whereas for 2 it is $\mathrm{F}^{-}>\mathrm{HSO}_{4}^{-}>\mathrm{Cl}^{-}>\mathrm{CH}_{3} \mathrm{COO}^{-}$, and $\mathrm{F}^{-}>\mathrm{Cl}^{-}>\mathrm{CH}_{3} \mathrm{COO}^{-}>\mathrm{HSO}_{4}^{-}$for 3 .

The authors would like to thank Dr. B.R. Ambedkar, National Institute of Technology, Jalandhar, Punjab, India and Hans Raj Mahila MahaVidyalaya, Jalandhar, Punjab, India for their support in carrying out the work. We gratefully acknowledge Mr. Avtar Singh and Mr. Manish, NMR Lab, SAIF, Punjab University, Chandigarh for recording the NMR spectra.

Supplementary data contain ${ }^{1} \mathrm{H}$ and ${ }^{13} \mathrm{C} \mathrm{NMR}$, mass spectra, and binding profiles for compounds $\mathbf{1}$, 2, 3, 4 and the crystal data for 1a, 1b, 2, 3, 4 in CIF format. Crystallographic data (excluding structure factors) for the structure in this paper $(\mathbf{1 a}, \mathbf{1 b}, \mathbf{2}, \mathbf{3}, \mathbf{4})$ have been deposited with the Cambridge Crystallographic Data Centre, as supplementary publication CCDC Nos. 898511, 916186, 898583, 924755, and 925940. Copies of the data can be obtained, free of charge, on application to CCDC, 12 Union Road, Cambridge CB2 1EZ, UK, (fax: +44-(0) 1223-336033 or e-mail: deposit@ccdc.cam.ac.uk.

\section{REFERENCES}

1. (a) Gale P.A., Sessler J.L., Kral V., Lynch V. // J. Am. Chem. Soc. - 1996. - 118. - P. 5140 - 5141 ; (b) Gale P.A., Sessler J.L., Kral V. // Chem. Commun. - 1998. - P. 1 - 8; (c) Sato W., Miyaji H., Sessler J.L. // Tetrahedron Lett. - 2000. - 41, N 35. - P. 6731 - 6736; (d) Camiolo S., Coles S.J., Gale P.A., Hursthouse M.B., Sessler J.L. // Acta Crystallogr. Sect. E. - 2001. - 57. - P. 816 - 817; (e) Garg B., Bisht T., Chauhan S.M.S. // New J. Chem. - 2010. - 34. - P. 1251 - 1254; (f) Aydogan A., Sessler J.L., Akar A., Lynch V. // Supramol. Chem. - 2008. - 20, N 1. - P. $11-21$.

2. (a) Camiolo S., Coles S.J., Gale P.A., Hursthouse M.B., Paver M.A. // Acta Crystallogr. Sect. E. - 2001. - 57. - P. 258 - 260; (b) Lynch V.M., Gale P.A., Sessler J.L., Madeiros D. // Acta Crystallogr. Sect. C. - 2001. - 57. - P. 1426 - 1428; (c) Nielsen K.A., Cho W.S., Jeppesen J.O., Lynch V.M., Becher J., Sessler J.L. // J. Am. Chem. Soc. - 2004. - 126, N 50. - P. 16296 - 16297.

3. (a) Custelcean R., Delmau L.H., Moyer B.A., Sessler J.L., Cho W.S., Gross D., Bates G.W., Brooks S.J., Light M.E., Gale P.A. // Angew. Chem. Int. Ed. - 2005. - 44. - P. 2537 - 2542; (b) Sessler J.L., Kim S.-K., Gross D.E., Lee C.-H., Kim J.-S., Lynch V.M. // J. Am. Chem. Soc. - 2008. - 130, N 39. - P. 13162 - 13166; (c) Wintergerst M.P., Levitskaia T.G., Moyer B.A., Sessler J.L., Delmau L.H. // J. Am. Chem. Soc. - 2008. - 130, N 12. - P. $4129-4139$.

4. (a) Farinha A.S.F., Tome A.C., Cavaleiro J.A.S. // Tetrahedron Lett. - 2010. - 51, N 16. - P. 2184 - 2187 ; (b) Gale P.A., Twyman L.J., Handlin C.I., Sessler J.L. // Chem. Commun. - 1999. - P. 1851 - 1852; (c) Nielsen K.A. // Tetrahedron Lett. - 2012. - 53. - P. 5616 - 5618; (d) Linn M.M., Poncio D.C., Machado V.G. // Tetrahedron Lett. - 2007. - 48. - P. 4547 - 4551; (e) Miyaji H., Anzenbacher Jr. P., Sessler J.L., Bleasdale E.R., Gale P.A. // Chem. Commun. - 1999. - P. 1723 - 1724.

5. Cafeo G., Kohnke F.H., Valenti L., White A. // J. Chemistry. - 2008. - 14, N 36. - P. $11593-11600$.

6. (a) Nielsen K.A., Jeppesen J.O., Levillain E., Becher J. // Angew. Chem. Int. Ed. - 2003. - 42. - P. 187 191; (b) Nielsen K.A., Cho W.-S., Lyskawa J., Levillain E., Lynch V.M., Sessler J.L., Jeppesen J.O. // J. Am. Chem. Soc. - 2006. - 128, N 7. - P. 2444 - 2451; (c) Gale P.A., Hursthouse M.B., Light M.E., Sessler J.L., Warriner C.N., Zimmerman R.S. // Tetrahedron Lett. - 2001. - 42. - P. $6759-6762$.

7. Kral V., Sessler J.L., Shishkanova T.V., Gale P.A., Volf R. // J. Am. Chem. Soc. - 1999. - 121. - P. 8771 8775 . 
8. (a) Sessler J.L., Gale P.A., Genge J.W. // Chem. Eur. J. - 1998. - 4. - P. 1095 - 1099; (b) Zhou C., Tang H., Shao S., Jiang S. // J. Liq. Chromatogr. Related Technol. - 2006. - 29, N 13. - P. 1961 - 1978; (c) Aydogan A., Akar A. // Tetrahedron Lett. - 2011. - 52, N 21. - P. 2790 - 2793.

9. (a) Allen W.E., Gale P.A., Brown C.T., Lynch V.M., Sessler J.L. // J. Am. Chem. Soc. - 1996. - 118. - P. 12471 - 12472; (b) Wu Y.-D., Wang D.-F., Sessler J.L. // J. Org. Chem. - 2001. - 66. - P. 3739 - 3746; (c) Blas J.R., Lopez-Bes J.M., Marquez M., Sessler J.L., Luque F.J., Orozco M. // Chem. Eur. J. - 2007. - 13. - P. 1108 - 1116; (d) Dey S., Pal K., Sarkar S. // Tetrahedron Lett. - 2007. - 48. - P. 5481 - 5485; (e) Ji X.K., Black D. StC., Colbran S.B., Craig D.C., Edbey K.M., Harper J.B., Willet G.D. // Tetrahedron. - 2005. - 61. - P. 10705 - 10712; (f) Dey S., Pal K., Sarkar S. // Tetrahedron Lett. - 2006. - 47. - P. 5851 5854.

10. (a) Nielsen K.A., Martin-Gomis L., Sarova G.H., Sanguinet L., Gross D.E., Fernandez-Lazaro F., Stein P.C., Levillain E., Sessler J.L., Guldi D.M., Sastre-Santos A., Jeppesen J.O. // Tetrahedron. - 2008. - 64. - P. 8449 8463; (b) Costero A.M., Gotor R., Gil S., Parra M., Ochando L.E., Chulvi K. // Org. Biomol. Chem. - 2012. - 10. - P. $8445-8451$.

11. (a) Anzenbacher P., Jursikova K., Lynch V.M., Gale P.A., Sessler J.L. // J. Am. Chem. Soc. - 1999. - 121. - P. 11020 - 11021; (b) Gil-Ramirez G., Escudero-Adan E.C., Benet Buchholz J., Ballester P. // Angew Chem. Int. Ed. - 2008. - 47. - P. 4114 - 4118; (c) Bonomo L., Solari E., Toraman G., Scopelliti R., Floriani C., Latronico M. // Chem Commun. - 1999. - P. 2413 - 2414; (d) Gil-Ramirez G., Benet-Buchholz J., Escudero-Adan E.C., Ballester P. // J. Am. Chem. Soc. - 2007. - 129. - P. $3820-3821$.

12. (a) Turner B., Botoshansky M., Eichen Y. // Angew. Chem. Int. Ed. - 1998. - 37. - P. 2475 - 2478 ; (b) Yang W., Yin Z., Li Z., He J., Cheng J.-P. // J. Mol. Struct. - 2008. - 889. - P. 279 - 285.

13. (a) Gale P.A., Sessler J.L., Allen W.E., Tvermoes N.A., Lynch V. // Chem. Commun. - 1997. - P. 665 - 666; (b) Anzenbacher P., Try A.C., Miyara H., Jurislorval K., Lynch V.M., Marquez M., Sessler J.L. // J. Am. Chem. Soc. - 2000. - 122. - P. 10268 - 10272; (c) Dey S., Pal K., Sarkar S. // Tetrahedron Lett. - 2008. - 49. - P. 960 - 964; (d) Hong S.-J., Yoo J., Kim S.-H., Kim J.-S., Yoon J., Lee C.-H. // Chem. Commun. $-2009 .-$ P. $189-191$.

14. (a) Ballester P., Gil-Ramírez G. // PNAS. - 2009. - 106, N 26. - P. 10455 - 10459; (b) Slovak S., EvanSalem T., Cohen Y. // Org. Lett. - 2010. - 12, N 21. - P. 4864 - 4867; (c) Barattucci A., Bonaccorsi P., Cafeo G., Kohnke F.H., Papalia T. // Tetrahedron. - 2011. - 67. - P. 7548 - 7556; (d) Espelt M., Ballester P. // Org. Lett. - 2012 - 14, N 22. - P. 5708 - 5711; (e) Ballester P. // J. Chem. - 2011. - 51, N 7. - P. 710 724.

15. (a) Anzenbacher Jr. P., Jursikova K., Sessler J.L. // J. Am. Chem. Soc. - 2000. - 122, N 38. - P. 9350 9351; (b) Song M.-Y., Na H.-K., Kim E.-Y., Lee S.-J., Kim K. I., Baek E.-M., Kim H.-S., An D. K., Lee C.-H. // Tetrahedron Lett. - 2004. - 45. - P. 299 - 301; (c) Bruno G., Cafeo G., Kohnke F.H., Nicolo F. // Tetrahedron. - 2007. - 63. - P. $10003-10010$.

16. (a) Camiolo S., Gale P.A. // Chem. Commun. - 2000. - P. 1129 - 1130; (b) Woods C.J., Camiolo S., Light M.E., Coles S.J., Hursthouse M.B., King M.A., Gale P.A., Essex J.W. // J. Am. Chem. Soc. - 2002. - 124. - P. $8644-8652$.

17. (a) Sheldrick G.M. // Acta Crystallogr. A. - 2008. - 64. - P. 112 - 122; (b) Farrugia L.J. // J. Appl. Crystallogr. - 1997. - 30. - P. 565; (c) Altomare A., Burla M.C., Camalli M., Cascarano G.L., Giacovazzo C., Guagliardi A., Moliterni A.G.G., Polidori G., Spagna R. // J. Appl. Crystalogr. - 1999. - 32. - P. 115 - 119; (d) Sheldrick G.M. SHELXTL/PC Siemens, XCANS, Siemens Analytical X-ray instruments Inc., Madison, Wisconison, USA, 1994.

18. Hynes M.J.J. // Chem. Soc. Dalton Trans. - 1993. - 2. - P. 311 - 312. 